\title{
Language and Sexual Difference
}

Feminist Writing in France

Susan Sellers

Macmillan Education 


\section{ISBN 978-0-333-44944-8 ISBN 978-1-349-21782-3 (eBook) \\ DOI 10.1007/978-1-349-21782-3}

(C) Susan Sellers, 1991

All rights reserved. For information, write:

Scholarly and Reference Division,

St. Martin's Press, Inc., 175 Fifth Avenue,

New York, N.Y. 10010

First published in the United States of America in 1991

ISBN 978-0-312-06161-6 (hardcover)

ISBN 978-0-312-06162-3 (paperback)

Library of Congress Cataloging-in-Publication Data

Sellers, Susan.

Language and sexual difference: feminist writing in France/

Susan Sellers

p. $\mathrm{cm}$.

Includes bibliographical references and index.

ISBN 978-0-312-06161-6. - ISBN 978-0-312-06162-3 (pbk.)

1. French literature--Women authors-History and criticism-

-Theory, etc. 2. French literature-20th century-History and criticism-Theory, etc. 3. Feminism and literature-France-

-History-20th century. 4. Women and literature-France-

-History-20th century. 5. Fiction-Authorship - sex differences.

6. French language - sex differences. I. Title.

PQ307.W6S45 1991

$840.9^{\prime} 9287-\mathrm{dc} 20$

91-9078

CIP 
For my mother and father 


\section{Contents}

Acknowledgements

Preface

Introduction 1

$\begin{array}{ll}\text { 1. Women and language } & 19\end{array}$

2. The (feminine) unconscious $\quad 39$

3. Theories of sexual difference $\quad 71$

4. A woman's language? 95

5. Towards an écriture féminine 131

Notes and references 163

$\begin{array}{ll}\text { Bibliography } & 185\end{array}$

$\begin{array}{ll}\text { Index } & 191\end{array}$ 


\section{Acknowledgements}

This book, like most others, could not have been written and would never have been completed without the help and support of family, friends, teachers, publishers and colleagues.

I would like to thank Hélène Cixous for her encouragement and inspiration, without which this project would never have happened, and Marguerite Sandré and Sarah Cornell, from whom I have learned so much.

I would like to thank Luce Irigaray, Julia Kristeva and Annie Leclerc for giving freely of their time to talk to me.

Jane Aaron's detailed and supportive reading of a first draft of this project was invaluable, as were initial discussions with Elizabeth Fallaize about French women's writing. I am also grateful to Elizabeth for acting as reader on the completed typescript.

Sue Roe read more drafts of this project than she probably cares to remember, and I am indebted to her not only for her constructive criticism, but for her patient and wise ear during numerous telephone and supper conversations. Alex Bennion and Adrienne Kern also read and commented on extracts from the typescript, and I am grateful to them for their belief that I would and could finish.

I am grateful to Margaret Whitford for the opportunity to discuss aspects of the book with her, for sending me articles and references, and for her encouragement.

I would like to thank my parents for providing me with a quiet corner in which to work, and Jonathan Wrobel for having faith in me and making the move to Paris possible.

I would like to thank Steven Kennedy for commenting on early drafts of the first chapters.

Jo Campling has been a beacon of practical help and emotional support throughout this project, and I am indebted to her for guiding me through the various stages of publication. 
The author and publishers wish to thank the following for permission to reproduce copyright material:

Basil Blackwell and Toril Moi for extracts from The Kristeva Reader; and Columbia University Press and Margaret Waller for extracts from Julia Kristeva's Revolution in Poetic Language.

Every effort has been made to contact all the copyright-holders, but if any have been inadvertently overlooked, the necessary arrangement will be made at the first opportunity. 


\section{Preface}

If I could somehow remain outside the scene ... I would risk asking the ... master a few questions. Which he would not hear.

Luce Irigaray

It is the world of words that creates the world of things.

Jacques Lacan 
My aims in this book are three. First I introduce the area of theory popularly known as 'French feminism' to non-French speakers by examining, with detailed reference to their theoretical and other writings, the works of Hélène Cixous, Luce Irigaray and Julia Kristeva. Secondly, in order to give a context to their work I have included introductions to the various theories that have shaped and influenced their writings, outlining the recent post-structural, linguistic, psychoanalytic and literary debates in France and, where appropriate, referring to a wider philosophical tradition. Thirdly, I shall demonstrate that whilst the writings of Hélène Cixous, Luce Irigaray and Julia Kristeva have been taken up by Anglo-American feminist critics as an important and challenging body of theory, both the issues that preoccupy them and a number of their conclusions are paralleled in the work of other French women theorists as well as in a range of contemporary French women's writing.

Although I have chosen, in line with common English usage, to retain the word 'feminist' in my title to refer to this body of writings, the appellation is in many ways inappropriate since few of the theorists or writers discussed here would unquestioningly accept the label as applying to their work. Both Hélène Cixous and Luce Irigaray, for instance, believe that the Anglo-American feminist preoccupation with equality forces women to function like men. Hélène Cixous to some extent side-steps the issue with her own definition of 'femininity', but since her definition needs explanation, and since there is no other word which adequately conveys the concern with subjectivity, sexuality and language that links the writers grouped in this book, I have retained the Anglo-American term 'feminist' which I use in its broadest sense to mean the challenge to the subordination of the female sex by a maledominated world order.

Transposing the English term feminist into the very different French context has not been the only translation problem I have encountered in the course of this study. Since my aim is to make French feminism accessible to non-French speakers I have, however, omitted from my commentary all but the most glaring and important translational changes. Where possible I have rooted my introductions in texts already translated into English. Since subjectivity lies at the heart of French feminist debate, it is nonetheless worth mentioning some of the difficulties involved in 
translating the French subject pronoun into English. Nouns in French carry either a masculine or a feminine gender - 'hand' is feminine, for example, while 'arm' is masculine - and thus the masculine French word for 'subject' (le sujet) theoretically incorporates both men and women within its meaning. A number of French feminists however argue that the subject, because of the way it is constituted within patriarchy, is masculine. The French masculine subject pronoun (il) therefore both includes (according to common usage grammar) and effectively excludes (according to French feminist theories of the subject) women. The equivalent English pronoun 'he' fails to convey this complexity, since it omits women in a way the French term does not: but neither does the now commonly adopted English form 's/he' seem appropriate. The occasionally used English pronoun 'they' sometimes offers a better solution, although its plural connotation does have the effect of undermining the unicity taken by some French feminists to be a characteristic feature of the (masculine) subject. At the same time, any deliberate attempt to stress the feminine - as in Hélène Cixous' use of the French feminine word for 'person' (la personne) - is also lost in an English translation. My answer to this linguistic minefield has been to respond according to specific instances, and to choose whichever English form seemed most appropriate in any given context.

The area of French feminist writing I have focused on has developed from different roots and in a different direction to the mainstream of Anglo-American feminism, as well as to other French feminisms. Anglo-American feminism, including its academic and critical branches, has, on the whole, evolved from a grassroots women's movement set up in the aftermath of the Civil Rights campaign in America, concerned to value women's experience and to protest against the political, social and economic injustices women endure, ${ }^{1}$ whereas the French feminist writing referred to here is in the main a response to a philosophical tradition. This writing does not represent the whole of French feminism: Simone de Beauvoir for example, a pioneering French feminist in the 1950s, wrote extensively on the importance of social conditioning in women's oppression, ${ }^{2}$ whilst the 1970 s saw an increase in the number of grass-roots women's groups and campaigns for equal rights in France. ${ }^{3}$ There are also many influential French feminists 
who refute the works of the theorists and writers I have included here for their 'ahistorical' reliance on biology and psychoanalysis (Monique Plaza) and for their failure to tackle the matericl conditions of women's lives (Christine Delphy). ${ }^{4}$

The link between the French feminist theorists and write:s grouped together in this book is their belief that the way forward for women lies not in achieving equality with men within the present system, but in challenging the system itself. For French feminists Hélène Cixous, Luce Irigaray and Julia Kristeva, our history, our philosophy, our system of government, our laws, even our religions, are the products of a specific - masculine - mode of perceiving and organising the world. To understand this structure they draw on the works of twentieth century French philosophers and cultural interpreters, and re-examine those philosophies - such as the Greek philosophy of Plato - that underpin our current system. ${ }^{5}$ To the French feminists included in this book our present system in the West is the result of a single - male - view of the world, encoded in our language and transmitted to us across centuries of learning so that it appears both natural and inevitable. It is in this sense that language is at the heart of French feminist debate. For many French theorists and writers it is language that embodies, carries and preserves man's vision of the world. The world has no intrinsic meaning prior to the structures we impose on it, and since it is in language that these structures are symbolised, language holds the key both to their understanding and to initiating change.

This emphasis has led to a number of differences with mainstream of Anglo-American feminism as well as other French feminisms. Whilst Anglo-American feminist critics have highlighted the role of language in women's oppression, stressing the power of 'naming' and the debilitating effects on women of our masculine or negative linguistic placing, ${ }^{6}$ their insistence has not been as marked as that of French feminist commentators. To writers like Hélène Cixous, Luce Irigaray and Julia Kristeva, language is not only intrinsic to the way we think - the way we perceive ourselves and others and construct both our public and private persona and our knowledge of the world - but its omissions and restrictions cannot be righted simply by adding women's voices to the debate, or by the type of surface changes - such as the transforming of 'chairman' into 'chairperson' - that have become such a feature of Anglo- 
American feminism. For many French feminists this endeavour is not only ineffective, since it fails to take account of the way the satriarchal system embodied in our language has repressed and made use of women's difference, but is even dangerous since it encourages women to believe we can achieve our potential within the existing system. To these French feminists, the Anglo-American emphasis on women articulating our experience and overcoming cur conditioning to become men's equals is thus the wrong insistence. Not only do many French feminists challenge the Anglo-American notion that language can communicate our experience without affecting or creating what we say, but they see the preoccupation with equality as perpetuating the status quo in its failure to tackle - or even to recognise - the patriarchal constructions on which our society depends. Language, because of the particular world-view it encodes, represses, excludes or appropriates all other constructions; and thus it is in the repressed, feminine or unconscious 'other' of language - what language does not say - that the feminist revolution must find a base.

This emphasis has also led to differences in the area of feminist criticism. Whilst Anglo-American concern to value women's experience has given rise, in literary study, to the search for a female literary tradition and the positive representation of women characters, ${ }^{7}$ for many French feminists this search is an erroneous one, since an 'other' (woman's) meaning can only exist in the gaps and blanks of our present language system. For these French feminists, the key is not what has been said, since this will inevitably be the result of our patriarchal schema and language, but the process by which meaning has been achieved. ${ }^{8}$

This emphasis has also given rise to a very different tradition of women's writing. Unlike the dominant realist modes of AngloAmerican feminist fiction, with their articulation of women's experience and their creation of positive role-models, ${ }^{9}$ to many French feminists these portrayals appear naive. Language encodes our experience, and because of the particular vision on which our language system depends, the problem for women is that we can only express ourselves in the language that symbolises the way man has perceived the world to be. Thus for many French feminist writers, the focus is not that of tracing or developing an authentic female voice, but on the contrary, lies in de-constructing the various symbolising procedures that hold the patriarchal vision in place, 
and which silence, distort and appropriate any other (woman's) view. To these French feminists, it is only by focusing on the processes by which language creates our meaning - as well as on what it omits - that women can begin to unravel the patriarcha. structure that encloses us and, by disobeying its laws, begin to change the way we are perceived and hence end the stranglehold of the patriarchal system itself.

This different development also has implications for the structure of this book. Since the writing included here has evolved largely in response to a philosophical tradition, I begin each section with a brief account of the various theories that have informed and motivated the writing. These introductions include both the immediate post-structural, linguistic and psychoanalytic debates that have had such an impact on French intellectual life in recent decades, and the broader philosophical context, ranging from the work of the influential seventeenth century French philosopher Rene Descartes to the philosophy of Plato. Since so many of the French feminist writers I refer to here have been influenced by this philosophy, I believe this context is important. I thus begin each section by citing the various debates that have informed French feminist writing on the subject, reiterating and developing, where necessary, any further contextual points. This has led to a different style in the presentation of the contextual (male) theories and the French feminist responses. Since these contextual debates are not my main interest here, I have selected from a range of texts by each writer only those points I feel are necessary to understanding the French feminist account, referring the reader in the Notes section to the relevant English translations and further introductions and commentaries. This contrasts with my presentation of French feminist theory, where I introduce each individual writer separately - where possible with detailed page references to a direct English translation - and where I have tried to keep each new reference within the confines of a single text. This has created a certain disjointedness in my overall argument, since in order to fully convey the scope of a particular text I have sometimes repeated points made earlier, or which logically belong to another section. I have also tried wherever possible to use the words and explanations of the writers themselves.

Since part of my aim is to show how the concerns of French feminist theory are reflected and worked through in a range of 
contemporary French women's fiction, each chapter, with the exception of the Introduction, also includes references to French women's fictional writing, selected to illustrate the theme of each chapter. One of the major challenges of French feminism is its insistence that women's oppression must be understood linguistically, and thus these examples are intended to show not only how the recurrent themes of language and women's difference are also the preoccupations of many French women writers, but how a strategy of disrupting the symbolising process can itself create new forms of representation which in turn alter the powerbalance of patriarchy. The space I have had available to present this wealth of women's writing has however been a limited one, and since, unlike the theory, very few of these texts are available in English, ${ }^{10}$ my introduction to the fiction has once again taken a different direction to that of the contextual and French feminist theories. Since this book is about the repressive effects of a 'master' discourse, I am only too aware of the dangers in attempting to paraphrase an argument or story-line; I have therefore chosen, for the presentation of the fictional examples, to quote extensively, using my own translation, from individual texts. I hope that these different styles of presentation will reinforce the French feminist thesis that there is no such thing as an objective or neutral language, and that by introducing this complex, challenging and highly stimulating body of writings in this way, I will encourage readers where possible to turn to the source-texts for themselves. 